\title{
A Textual Note on Epim. Hom. \& 268 Dyck (Vol. II)
}

\author{
Federico Favi \\ Oriel College, University of Oxford \\ federico.favi@classics.ox.ac.uk
}

Received May 2019| Accepted August 2019

The gloss Epim. Hom. $\alpha 268$ Dyck (Vol. II $)^{1}$ is entirely devoted to $\alpha \dot{\tau} \tau \eta$. The central section deals with the eight peculiarities of avंtós. For the sake of the present discussion, it is only needed to report the first five:

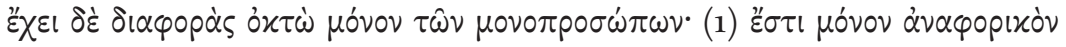

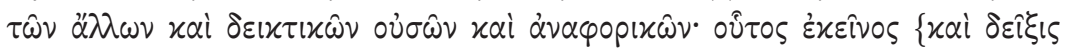

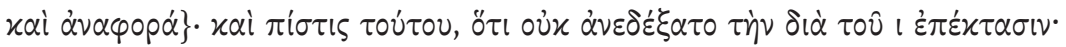

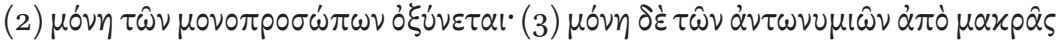

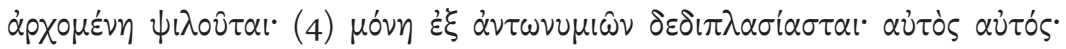

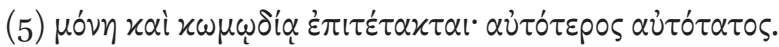

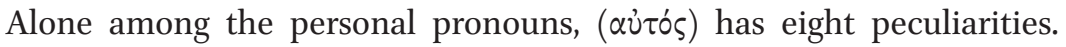
(1) It is only anaphoric, whereas the others are both deictic and anaphor-

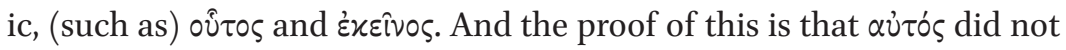
admit of the suffixation -ı. (2) Only this among the personal pronouns is oxytone. (3) Only this among the pronouns, though beginning with a long first syllable, does not have the aspiration. (4) Only this among the pronouns is duplicated: aùtòs aủ tós. (5) Only this is imposed to comedy:

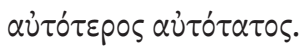

The fifth peculiarity poses some textual problems. ${ }^{2}$ The manuscripts of the Epimerismi Homerici unanimously transmit the text above. Dyck does not

1 Dyck 1995, 153-154.

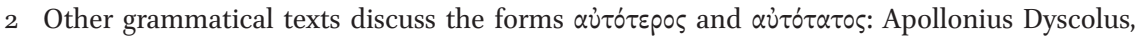
Pronouns (ed. Schneider, Grammatici Graeci vol. II.I p. 63.20 = Brandenburg 2005, 399):

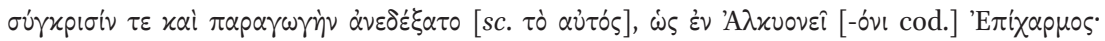

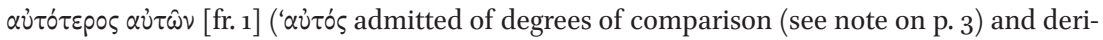
vation'); Scholia Marciana in Dionysii Thracis artem grammaticam (ed. Hilgard, Grammatici 


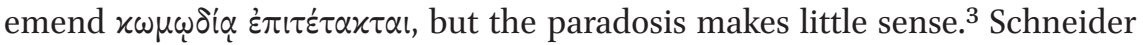

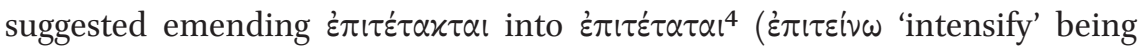
common grammatical vocabulary), ${ }^{5}$ in which case the reference would be to the comparative $\alpha \dot{v} \tau o ́ \tau \varepsilon p o \varsigma$ and superlative $\alpha \dot{\tau} \tau o \dot{\tau} \alpha \tau o \zeta$. Schneider's conjecture is very reasonable and should be accepted without further ado (thus also K-A ad Epich. fr. 1). Ludwich's emendation $x \dot{\alpha} \nu<\tau \hat{\eta}>\varkappa \omega \mu \omega \delta i^{6} \alpha^{6}$ for transmitted $x \alpha i$ $\chi \omega \mu \omega \delta$ í $\alpha$ would make sense of the isolated dative, but 'also in comedy' remains

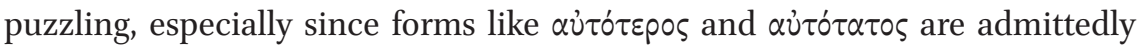
only attested in comedy (see below; K-A ad Epich. fr. 1 do not accept this emendation either). The position of $x \alpha$ i after $\mu$ óv $\eta$ at the beginning of the sentence makes it unlikely that $x$ i may be linking this section of the gloss with the preceding one, and therefore $x a$ i is more likely to be taken with what follows. ${ }^{7}$ Besides, all entries in the Epimerismi gloss are introduced by a bare $\mu$ óv $(\mathrm{ex}-$ cept the third one, which is connected to the preceding one with $\delta \dot{\varepsilon}$ ), and only the subsections within the sixth and ninth peculiarity are linked to one another with connectives. Another possibility would be to emend the paradosis

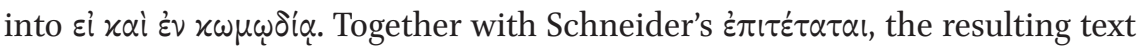
would be:

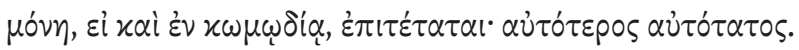

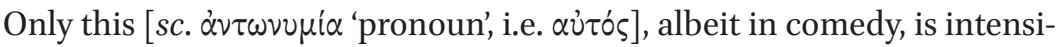

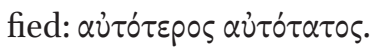

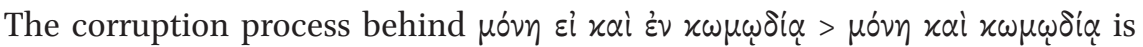
straightforward, and may be easily explained through vocalic homopho-

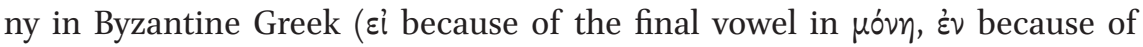
preceding $x \alpha i)$.

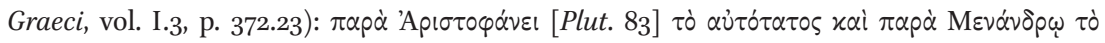

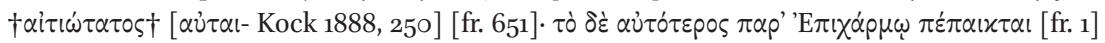

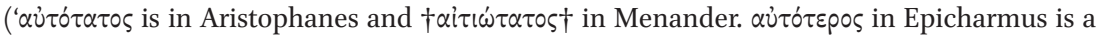
jocular form'); Scholia vetera in Aristophanis Plutum (ed. Chantry, line $83=$ Sud. $\alpha 4529$ Adler):

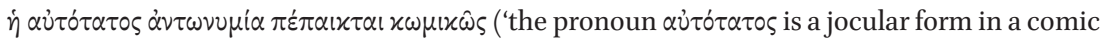
fashion'). See further Scholia vetera in Aristophanis Plutum (ed. Chantry, line 83, a-c-d-e).

3 Dyck 1995, 153 .

4 Schneider 1902, 88.

5 See Dickey 2007, 238.

6 Ludwich 1902, col. 8 o6.

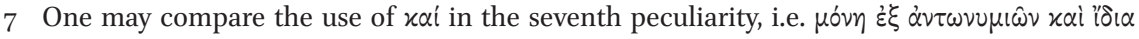

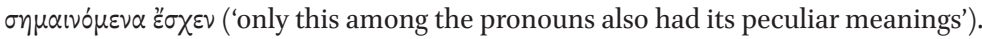




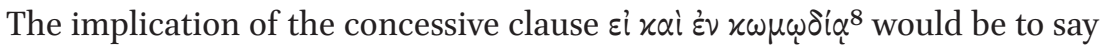
that aũós is indeed peculiar, in that this is the only pronoun which has a com-

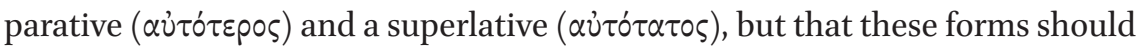
not be taken at face value, since they are only used in comedy, where they serve a comic purpose. Such an observation is well paralleled in the other grammatical

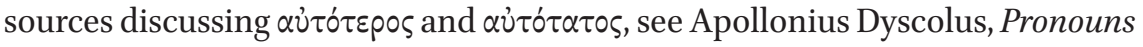
(ed. Schneider, Grammatici Graeci vol. II.I p. 64.11 = Brandenburg 2005, 400-

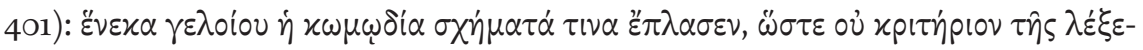

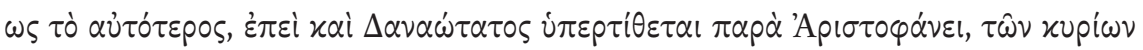

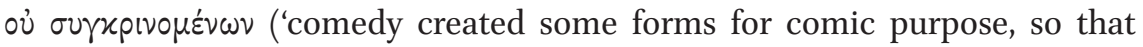

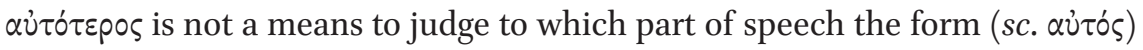
belongs, ${ }^{9}$ since $\Delta \alpha v \alpha \omega \tau \tau \tau \tau o \zeta$ too is created as a superlative in Aristophanes, though proper names do not have degrees of comparison'); Scholia Marciana in Dionysii Thracis artem grammaticam (ed. Hilgard, Grammatici Graeci vol. I.3

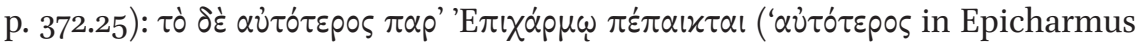
is a jocular form'); Scholia vetera in Aristophanis Plutum (ed. Chantry, line 83

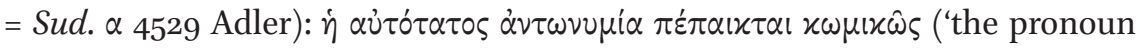
$\alpha$ ¿̇ंó $\tau \alpha \tau o \zeta$ is a jocular form in a comic fashion'). Interestingly, this doctrine has influenced the Latin grammarian Pompeius who discusses the comic superlative ipsissimus in Plautus and Afranius ${ }^{10}$ (Pompeii commentum artis Donati, ed. Keil, Grammatici Latini V p. 153.13: ergo vides, quae nomina conparantur: quae sunt qualitatis et quantitatis. ea autem, quae non sunt qualitatis et quantitatis, non recipiunt comparationem. ne te decipiant illa Plautina [Tr. 988] et Afraniana [432 CRF] verba, ipsissimus; ioco comico hoc dixit. est etiam apud

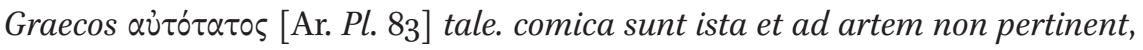
'therefore you see which names have degrees of comparison: those which express a quality or a quantity. Whereas those which do not, do not have degrees of comparison. Do not be misled by the word ipsissimus used by Plautus and

8 For the use of concessive $\varepsilon i$ xal in the Epimerismi Homerici one may compare e.g. Epim.

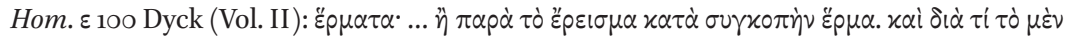

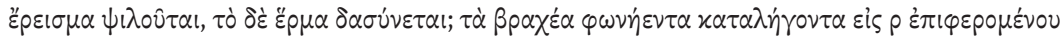

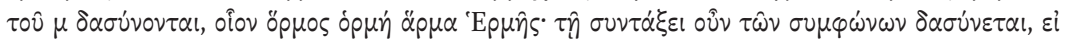

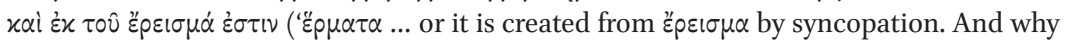

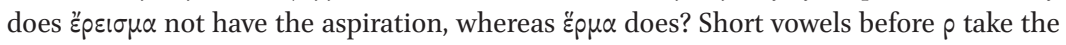

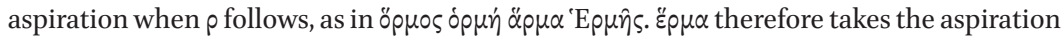
because of the combination of consonants, even though it is from है $\left.\rho \varepsilon เ \sigma \mu \alpha^{\prime}\right)$.

9 On this last sentence, see Schneider 1910, 219 and Brandenburg 2005, 401.

10 This form is also attested in Petronius (63,3; 69,3; 75,11; 76,1; see Schmeling 2011, 260). 


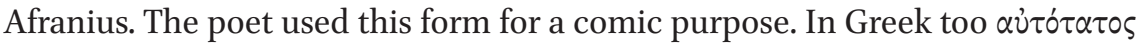
is such. These are comic forms, and do not pertain to the grammar'). ${ }^{11}$

\section{Acknowledgements}

I am grateful to Luigi Battezzato and the anonymous referee for their valuable advice and to Il-Kweon Sir and Theodore Hill for improving the English. I am solely responsible for any remaining error or misjudgements. This research was funded by a British Academy Postdoctoral Fellowship.

\section{Bibliography}

Brandenburg, P. (2005). Apollonius Dyskolos, Über das Pronomen. Einführung, Text, Übersetzung und Erläuterungen. München/Leipzig.

Dickey, E. (2007). Ancient Greek Scholarship. A Guide to Finding, Reading, and Understanding Scholia, Commentaries, Lexica and Grammatical Treaties, from their Beginnings to the Byzantine Period. Oxford.

Dyck, A.R. (1995). Epimerismi Homerici. Pars Altera: Epimerismos continens qui ordine

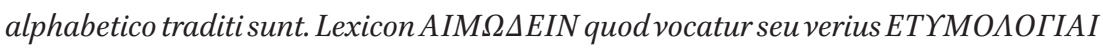
$\triangle I A Ф O P O I$. Berlin/New York.

Kock, T. (1888). Comicorum Atticorum Fragmenta, Vol. 3: Novae comoediae fragmenta. Pars II: Comicorum incertae aetatis fragmenta. Fragmenta incertorum poetarum. Indices. Supplementa. Leipzig.

Ludwich, A. (1902). Review of Schneider. Berliner philologische Wochenschrift 22, coll. 8o1-810.

Schmeling, G. (2011). A Commentary on the Satyrica of Petronius. With the collaboration of Aldo Setaioli. Oxford.

Schneider, R. (1902). Grammatici Graeci II/II. Commentarius criticus et exegeticus in Apollonii scripta minora. Leipzig.

Schneider, R. (1910). Grammatici Graeci II/III. Librorum Apollonii deperditorum fragmenta collegit disposuit explicavit. Indices omnium librorum confecit. Leipzig.

11 Priscian is less selective on this point, see Prisciani grammatici Caesariensis institutionum grammaticarum (ed. Keil, Grammatici Latini II p. 84.9-11). 